\title{
Ayurvedic Literature Review of Pratishyaya w.s.r. Rhinitis
}

\author{
Journal of Pharmaceutical Research and Development
}

Review Article

Pinki Meena ${ }^{1}$, Aparna Sharma ${ }^{2}$, Ish Sharma ${ }^{3^{*}}$

${ }^{1} P G$ Scholar, Shalakya Tantra Department, National Institute of Ayurveda, Jaipur, Rajasthan, India

${ }^{2}$ Associate Professor, Shalakya Tantra Department, National Institute of Ayurveda, Jaipur, Rajasthan, India

${ }^{3}$ The Controller of Examinations, Guru Ravidas Ayurved University, Punjab, Hoshiarpur, India

\author{
*Correspondence author \\ Ish Sharma \\ The Controller of Examinations \\ Guru Ravidas Ayurved University \\ Punjab \\ Hoshiarpur \\ India
}

Submitted : 18 Aug 2020 ; Published : 16 Nov 2020

\begin{abstract}
Ayurveda is the ancient most medicine science with equal emphasis upon prevention and cure. Due to environmental pollution, global warming, and life style disorders, a very common disease, Pratishyaya/Rhinitis occurs much more frequently than before. Pratishyaya has been considered as a separate clinical condition in Uttar Tantra of Sushruta Samhita. Improper management or negligence can lead to lots of complications like Badhirya, Andhata, Gandhanasha, Kasa etc. Rhinitis is an inflammation of the nasal membranes, characterized by watery nasal discharge, nasal obstruction, sneezing and nasal itching. This may also be associated with symptoms of itching in the eyes, palate and pharynx. Many treatment modalities are explained in modern system of medicine like corticosteroids, antiallergics, inhalers, antihistamines etc., but none of them are totally effective in curing the disease as well as preventing its recurrence, more over they have their own side effects.
\end{abstract}

Keywords: Pratishayaya; Ayurveda; Rhinitis.

\section{Introduction}

The human body is continuously under the influence of environmental stresses as pollution, chemicals, pesticides, genetically modified food, smoke and errant diet as untimely meals, over eating, cold drinks, ice cream etc., which gives rise to respiratory tract disease. These factors lower the immunity of nasal mucosal membrane leading to various diseases. Among these diseases, Pratishyaya is a very common one.

Pratishyaya is described since Samhita kala in Brihattrayee as well as Laghutrayee. It is described as a premonitory symptom/ purvarupa of Tuberculosis/Rajyakshma and as a symptom of Vega vidharanaj, Kshayaja and Vishamasanaja Yakshma. In Sushruta Samhita, it is given in more detailed as a separate chapter.

Acharya Charaka described Pratishyaya as a lakshana of Sahasajanya, Dhatukshayaj, Sandharanajanya and Vishamashanaj Shosha in the chapter-Shoshanidan of Nidan Sthana. In eighth chapter-Rajyayakshma chikitsadhyaya of Chikitsa Sthana, Pratishyaya is given as a purvarupa and lakshana of Yakshma. In this chapter, samprapti as well as general treatment of Pinas (Pratishyaya) is described. In twenty sixth chapterTrimarmiya chikitsaadhyaya, nidana and pathya of Pratishyaya is given. The Symptoms as well as treatment of specific types of
Pratishyaya i.e. Vataj, Pittaj, Kaphaj and Sannipataj Pratishyaya is described in this chapter. If patients neglect, all types of Pratishyaya, it can change into Dushta Pratishyaya.

According to Ayurveda, Pratishyaya is one of the most important disease among Nasa roga (Nasal Disease) defined as a condition where the secretion produced due to vitiation of Vata and Kapha at the root of nose which flows down through the nose against the inspired air [1]. Acharya Susruta has described five types of Pratishyaya among in 31 nasaroga [2].

\section{Etymology: Prati + Shyeng + Gatav $=$ Pratishyaya}

The word Pratishyaya is derived from "Shyeng" Dhatu which refers to move, when this Dhatu is prefixed by "Prati" and suffixed by "Gatav", the word Pratishyaya is form.

Definition: The word Pratishyaya is derived from two words "prati" and "shyaya".

Prati-against the direction

Shyaya - moving or flowing 
Acharya Charaka defined it as Kapha, Pitta, Rakta which being present in Ghrana moola, combines with Vata Dosha resulting in the secretion which flow against the inspired air [3].

Importance of Pratishyaya

1. Pratishyaya is the causative condition for all the other diseases of the nasal cavity, and hence it is explained with priority in the nasarogas.

2. Pratishyaya is the only disease explained in Shalakya tantra which develops complications even before the signs and symptoms occur. Hence if treated when the purvaroopas are seen, the further pathology can be stopped.

Considering all these facts, Pratishyaya has a special importance and should be treated as soon as detected in its initial stages.

Nidana of Pratishyaya - Nidana of Pratishyaya are classified under

1. Sadyojanaka Nidana

2. Kalantarajanaka Nidana

\begin{tabular}{|l|l|l|l|l|}
\hline Aharaj Nidana & Charaka[4] & Sushruta[5] & Vaghbhat[6] & Kashyapa[7] \\
\hline Ajeerna & + & - & - & - \\
\hline Sheeta Ambu & + & - & - & - \\
\hline Ati Ambupana & - & - & + & + \\
\hline Mandagni & - & - & - & + \\
\hline Dvividha Dughapana & - & - & - & + \\
\hline Excessive intake of Guru, Madhura, Sheeta padarthas & - & - & - & + \\
\hline Vismashana & - & - & - & + \\
\hline $\begin{array}{l}\text { Intake of Ati Sheeta Jala by persons of Shleshma } \\
\text { Prakriti }\end{array}$ & - & - & - & + \\
\hline
\end{tabular}

Table 1: Nidana of Pratishyaya

\begin{tabular}{|c|c|c|c|c|}
\hline Viharaja Nidana & Charaka & Sushruta & Vaghbhat & Kashyapa \\
\hline Vega Sandharana & + & + & + & + \\
\hline Rajah Sevan & + & + & + & \\
\hline Dhooma Sevana & + & + & - & - \\
\hline Ati Bhasana & + & - & + & - \\
\hline Ritu Vaishamya & + & - & - & - \\
\hline Shirobhitapa & + & + & - & - \\
\hline Ratri jagarana & + & - & + & - \\
\hline Ati Divaswapana & + & - & + & - \\
\hline Avasyaya & + & + & + & \\
\hline Ati Nariprasanga & + & + & - & - \\
\hline Ati Jala Krida & - & - & + & - \\
\hline Ati Pratapa & - & + & - & - \\
\hline Ati Ashru Srava & + & - & - & - \\
\hline Neechaatiucchaupadhan & - & - & + & - \\
\hline Ati Parshwa Shayana & - & - & - & + \\
\hline $\begin{array}{l}\text { Nitya Anupahita } \\
\text { Shayana }\end{array}$ & - & - & - & + \\
\hline $\begin{array}{l}\text { Apavrita Mukha } \\
\text { Shayaya }\end{array}$ & - & - & - & + \\
\hline Snana with Sheeta Jala & - & - & - & + \\
\hline
\end{tabular}

\begin{tabular}{|l|l|l|l|l|}
\hline Manasika Nidana & Charaka & Sushruta & Vaghbhatta & Kashyapa \\
\hline Ati Krodha & + & - & - & - \\
\hline
\end{tabular}

Stages of Pratishyaya

Acharya Dalhana described two stages of Pratishyaya as [8] - (1) Amavastha (2) Pakwavastha 
Amavastha: The symptoms are- Aruchi, Vaktravirasam, Nasasrava, Ruja, Arati, Shirogurutvam, Kshvathu and Jwara.

Pakwavastha: This stage comes after the Amavastha in which Tanutvamamalingam, Shirah Nasa Laghuta and Ghanapittakaphatvam are the symptoms.

\section{SAMPRAPTI}

These etiological factors of rhinitis provoke the pathology in a different way through the Shadkriyakala.

Here Vata, Pitta, Kapha and Rakta gets vitiated with their own etiologically factors. The vitiated Vata when reaches Shira Pradesha Kapha, Pitta and Rakta avarana of Dosha for the gati of Vata and Doshas get lodged in Shira Pradesha. Vriddha Vata expels out Kapha, Pitta and Rakta through nasal route thus giving rise to the disease Pratishyaya [9].

Observing the causative factors, allergy is noted as an important etiology. As practically seen, $20 \%$ of population does suffer from one or another allergy sometime in life [22].

PURVA ROOPA - It has been stated by Sushruta. Madhava Nidana and Bhavprakash have followed Sushruta in describing the purvaroopa [12].

1. Shirogurutvam (heaviness in the head)

2. Kshvathu Pravartanam (Sneezing)

3. Angamarda (Bodyache)

4. Parihristaromta (Generalised horripilation)

Classification

Acharya Susruta, Vagbhat, Madhavakar, Bhava Mishra, Sharangadhara have described five types of Pratishyaya on basis of Doshas. But Acharya Charaka and Kashyapa have not accepted Raktaja Pratishyaya [10, 11]. According to Rasa Ratna Samuchchaya, there are six types of Pratishyaya.

Vataja Pratishyaya - Clinical features according to Charaka (C.Ch.26/105)

\begin{tabular}{|l|l|}
\hline Ghranarti Toda & Pricking pain sensation in nose \\
\hline Kshavathu & Sneezing \\
\hline Jalabhsrava & Watery nasal discharge \\
\hline Swarabheda & Hoarseness in voice \\
\hline Shirashoola & Headache \\
\hline
\end{tabular}

Clinical features according to Sushruta (Su.Ut.24/6-7), Madhava Nidana \& Bhava Mishra

\begin{tabular}{|l|l|}
\hline Anadhapihita nasa & Nasal obstruction and stiffness \\
\hline Tanusrava pravartini & Watery nasal discharge \\
\hline Galtalvoshath shosha & Dryness in throat, palate, lips \\
\hline Shankh nistoda & $\begin{array}{l}\text { Pricking sensation in temporal } \\
\text { region }\end{array}$ \\
\hline Swaropghata & Hoarseness in voice \\
\hline
\end{tabular}

Clinical features according to Vaghbhat (A.H.Ut.19/3-4)

\begin{tabular}{|l|l|}
\hline Mukhshosha & Dryness in mouth \\
\hline Bhranshm shava & Sneezing \\
\hline Ghranoprodha & Nasal blockage \\
\hline Nistoda danta shankh & $\begin{array}{l}\text { Pricking sensation in temporal } \\
\text { region,teeth }\end{array}$ \\
\hline Shirovaytha & Headache \\
\hline Kitika ev Sarpanti & $\begin{array}{l}\text { Ant moving like feeling around the } \\
\text { eyebrows }\end{array}$ \\
\hline Swarsaad & Hoarseness in voice \\
\hline Chiratpaka & Late viscous secretion \\
\hline Shishira Kaphashruti & Watery nasal secretion \\
\hline
\end{tabular}

Pittaja Pratishyaya - Clinical features according to Charaka (C.Chi.26/106)

\begin{tabular}{|l|l|}
\hline Nasagrapaka & Inflammation of tip of nose \\
\hline Jwara & Fever \\
\hline Vaktrashosha & Dryness in mouth \\
\hline Trishna & Thirst \\
\hline Ushnapittasrava & Hot \& yellow nasal discharge \\
\hline
\end{tabular}

Clinical features according to Sushruta (S.S.Ut.24/8), Madhava Nidana \& Bhava Mishra

\begin{tabular}{|l|l|}
\hline Ushnapittaksrava & Hot \& yellow nasal discharge \\
\hline Krishata & Weakness \\
\hline Panduta & Pallor \\
\hline Trishna & Thirst \\
\hline Dhumra-vahini-vamana & Vomiting \\
\hline
\end{tabular}

Clinical features according to Vaghbhat (A.H.Us.19/5)

\begin{tabular}{|l|l|}
\hline Trishna & Thirst \\
\hline Jwara & Fever \\
\hline Ghranapitika & Furuncles in nose \\
\hline Bhrama & Giddiness \\
\hline Nasagrapaka & Inflammation of tip of nose \\
\hline Ushnatamrapittasrava & Hot \& yellow nasal discharge \\
\hline
\end{tabular}

Kaphaja Pratishyaya- Clinical features according to Charaka (C.Chi.26/106)

\begin{tabular}{|l|l|}
\hline Kasa & Cough \\
\hline Aruchi & Anorexia \\
\hline Ghanasrava & Thick nasal discharge \\
\hline Kandu & Ithching \\
\hline
\end{tabular}

Clinical features according to Sushruta (S.S.Ut.24/9), Madhav Nidana \& Bhav Mishra 


\begin{tabular}{|l|l|}
\hline Shukla-sheeta srava & Whitish nasal discharge \\
\hline Shuklaavabhasa & Feeling of whitish all around \\
\hline Shoonakshi & Swelling in eyes \\
\hline Guru shiro-mukha & Heaviness in head \& mouth \\
\hline Shirogalosthatalukandu & $\begin{array}{l}\text { Itching in head, throat, lips } \\
\text { and palate }\end{array}$ \\
\hline
\end{tabular}

Clinical features according to Vaghbhat (A.H.Us.19/6)

\begin{tabular}{|l|l|}
\hline Aruchi & Anorexia \\
\hline Shwasa & Difficulty in breathing \\
\hline Vamana & Vomiting \\
\hline Gatragaurava & Heaviness in body \\
\hline Mukha madhurya & Sweetness in mouth \\
\hline Kandu & Itching \\
\hline Shukla-kaphasruti & Whitish nasal discharge \\
\hline
\end{tabular}

Raktaja Pratishyaya

According to Charaka: he has not described Raktaja Pratishyaya.

Clinical features according to Sushruta (S.S.Ut.24/12-13), Madhava Nidana and Bhava Mishra

\begin{tabular}{|l|l|}
\hline Rakta srava & Bleeding from nose \\
\hline Tamrakshi & Copper coloured eyes \\
\hline Daurgandha Swasa Vadan & Foul breathing \\
\hline Gandhan na vetti & Loss of sense of smell \\
\hline Krimipatana & Worms fall from nose \\
\hline
\end{tabular}

Clinical features according to Vaghbhat (A.H.U.19/8)

\begin{tabular}{|l|l|}
\hline Urah suptata & Stiffness in chest \\
\hline Tamranetra & Copper coloured eyes \\
\hline Swasaputita & Foul breathing \\
\hline $\begin{array}{l}\text { Shrotra-akshi-nasa } \\
\text { kandu }\end{array}$ & Itching in ear, eye and nose \\
\hline Pittokta lakshanam & $\begin{array}{l}\text { Characteristics of pittaja } \\
\text { Pratishyaya }\end{array}$ \\
\hline
\end{tabular}

Sannipataja Pratishyaya

According to Charaka: Symptoms are Sarvanirupani, Tivraruja, Dukhadayee. (C.Chi.26/106).

According to Susruta: it occurs again and again but stops suddenly. (Su.Ut.24/10-11)

According to Vagbhat: Symptoms are Sarvaja lakshana, Akasmat vridhishanti. (A.H.Ut.19/7).

Dusta Pratishyaya: If Pratishyaya not treated properly, leads to Dust Pratishyaya.

Management of Pratishyaya

The dietary measures, medications for Sodhana and Shaman and various treatment modalities for Pratishyaya are explained in detail by Acharya Sushruta [13].

The first step in the treatment is Nidana-Parivarjan. As only local treatment is not enough to treat the disease, oral medication is also necessary which helps to remove the pathology and also improves the immunity status.

As per Acharya Sushruta, Langhana along with deepana and pachana dravyas, Swedana, Vamana, Avapeedana Nasya and ghrita pana (except Navin Pratishyaya) are the common treatment methodologies suggested in all types of Pratishyaya. Panchakarma is of significant detox value against all the three Tridosha [21].

Treatment of Apakva Pratishyaya - Swedana from Kanji etc. Amla pathartha, intake of hot substances, use of milk mix with Adarka and use of ekshu preparation like Gud, Fanita yoga etc [14].

Treatment of Pakva Pratishyaya - Tikshna Shirovirachana, Dhoompana, Asthapana basti, Kaval, Nasya and use of Haritaki [15].

\section{Treatment of Vataja Pratishyaya [16]}

- Ghritapana - Oran administration of Panch lavan siddha ghrita and Vidharigandhadi gana sidhha ghrita.

- Nasya

- Arditokta chikitsa-Shirobasti, Nasya, Dhooma, Upnaha, Sneha \& Nadi Swadana, Ksheer taila pana and Abhayang.

Treatment of Pittaja \& Raktaja Pratishyaya [17]

- Ghritapana

- Perisheka

- $\quad$ Pradeha

- Virechan

- Nasya

Exclusive treatment

1. Oral administration - Kakolyadi gana siddha ghritapana and Shreeveshtaka, Sarjarasa, Priyanghu, Madhu, Sarkra, Draksha, Madhulika, Gojihva, Gambhari, Madhuka mix with ghee.

2. Parisheka - from Sheeta Dravyas.

3. Pradeha - from Sheeta Dravyas.

4. Virechan - from Madhura dravyas

5. Nasya-Dhavtwak, Triphala, shyama, Tilvaka, Madhuka, Shreeparni, Haridra rubbed with water, milk and tila taila used for Nasya.

Treatment of Kaphaja Pratishyaya [18]

1. Ghritapana

2. Yavaghu pana

3. Vaman

4. Kaphaghna Karma

5. Nasya 
6. Dhoompana

Exclusive treatment

1. Yavaghu pana - Yavaghu preparation of Tila and Masha.

2. Nasya - Bala, Atibala, choti Kantkari, badi Kantkari, Vidang, Goshura, Swetamoola, Gambhari, Punarnava rubbed with Tila taila used for Nasya.

3. Dhoompana-Sarla, Kinhi, Devdaru, Nikumbha, Hinghota rubbed with water and make Varti, used for Dhoompana.

Treatment of Sannipataja Pratishyaya [19]

- Ghritapana

- Tikshna dhoompana

- Use of Katu Aushadi

- Nasya

- Kavala

- Shirovirechana

Exclusive Treatment

1. Nasya - Rasanjan, Atish, Musta, Devdaru rubbed and mix in Tila taila and water used for Nasya. Jangal meat, milk, Dashmool, Vidharigandhadi gana drugs rubbed and mix with Eladigana drugs \& ghee, used for Nasya.

2. Kavala-Decoction of Musta, Tejovati, Patha, Katphala, Katuka, Vacha, Sarspa, Pippalimoola, Pippali, Sandhav, Chitraka, Tutha, Kranja, Lavan, Devdaru. Also used as Shirovirechan (Taila preparation).

Sushruta has specially mentioned krimighna chikitsa such as use of Vidangadi medicine in Nasya form and Krimighna Karma [20].

\section{Certain Instructions to be followed}

- $\quad$ The patient suffering from pratishyaya should avoid cold breeze and polluted air.

- It is advisable to use a mask or cover the face and nose to avoid pollutants and causative organisms to enter the nose.

- Artificially cooled air should be avoided as it absorbs all the moisture and causes severe drying effect of the nasal mucosa.

- Regular nasal douching should be done with saline water to reduce the crusting of the nasal mucosa. Regular Nasya chikitsa should be followed.

\section{Conclusion}

Ayurvedic formulations can be adopted for more effective, non chemical treatment of Pratishyaya. All formulations are proposed to be taken up for evaluation of their effect in Pratishyaya w.s.r to rhinitis to come up with safe and cost effective treatment for this ailment.

\section{References}

1. Sharma RK and Dash B (2001). Agnivesa's Charaka Samhita (Text with English translation \& critical. Exposition based on Cakrapani Dutta's Ayurveda Dipika) $2^{\text {nd }}$ Edition, Varanasi, India, Chaukhambha Sanskrit Series Office.

2. Susruta Samhita edited with Ayurveda Tattva Sandipika Hindi commentary by Kaviraja Ambikadutta Shastri Chaukhambha Sanskrit Sansthan, Varanasi (2013), UttaraTantra 22/3-5, p. 135.

3. Charaka Samhita, Vidyotini Hindi commentary by Pt. Kasinatha Sastri and Gorakha Natha Chaturvedi, Chaukhambha Bharti Academy, Varanasi, Reprinted 2013, Chikitsa Stana 8/48-49, p. 285.

4. Charaka Samhita, Vidyotini Hindi commentary by Pt. Kasinatha Sastri and Gorakha Natha Chaturvedi, Chaukhambha Bharti Academy, Varanasi, Reprinted 2013, Chikitsa Stana 26/104, p. 736.

5. Sushruta Samhita, commentaries by Shastri, Kaviraja Ambikadatta 'Ayurveda Tattva Sandipika' Chaukhambha Sanskrit Sansthan, Varanasi, India, Reprinted in 2013, Uttar Stana 24/3-4, p. 153.

6. Ashang Hrdayam, Vidyotini Hindi commentary by Kaviraj Atrideva Gupta edited by Vaidya Yadunandana Upadhyaya, Chaukhambha Prakashan, Varanasi, Uttar Stana 19/1-2, p. 701.

7. Maharshi Mareecha Kashyapa, Vriddhajeevakatantra Revised by Vatsya with Sanskrit Introduction by Nepal Rajguru, Pandit Hemaraja Sharma with the Vidyotini Hindi commentary \& Hindi translation of Sanskrit Introduction by Ayurvedalankara Shri Satyapala Bhishagacha, Varanasi, $9^{\text {th }}$ Edition, Choukamba Sanskrit Samsthan Publication, 2004, Ka. Chi 12/3.

8. Sushruta Samhita, with Nibandha Sangraha commentary of Shree Dalhanacharya and the Nyayachandrika Panjika of Shri Gayadasacharya on Nidanasthana, edited by Vaidya Jadavji trikamji Acharya and Narayan Ram Acharyakavyatirtha, Uttara Tantra 24/16-17, p. 652.

9. Sushruta, Sushruta Samhita, commentaries by Shastri, Kaviraja Ambikadatta 'Ayurveda Tattva Sandipika' Chaukhambha Sanskrit Sansthan, Varanasi, India, Reprinted in 2013, Uttar Stana 24/4, p. 153.

10. Agnivesha, Charakasamhita, elaborated by Charaka and Dridhabala, with the Ayurveda- Deepika commentary be Chakrapanidatta, edited by Vaidya Jadavaji Trikamji Achary, published by Choukhamba Publications, Varanasi, Chikitsa Sthana 26/110-114, pp. 604-605.

11. Maharshi Mareecha Kashyapa, Vriddhajeevakatantra Revised by Vatsya with Sanskrit Introduction by Nepal Rajguru, Pandit Hemaraja Sharma with the Vidyotini Hindi commentary \& Hindi translation of Sanskrit Introduction by Ayurvedalankara Shri Satyapala Bhishagacha, Varanasi, 
$9^{\text {th }}$ Edition, Choukamba Sanskrit Samsthan Publication, 2004, Ka. Chi 12/5-6, p. 222.

12. Sushruta Samhita, commentaries by Shastri, Kaviraja Ambikadatta 'Ayurveda Tattva Sandipika' Chaukhambha Sanskrit Sansthan, Varanasi, India, Reprinted in 2013, Uttar Stana 24/5, p. 153.

13. Sushruta Samhita, commentaries by Shastri, Kaviraja Ambikadatta 'Ayurveda Tattva Sandipika' Chaukhambha Sanskrit Sansthan, Varanasi, India, Reprinted in 2013, Uttar Stana 24/18, p. 155.

14. Sushruta Samhita, commentaries by Shastri, Kaviraja Ambikadatta 'Ayurveda Tattva Sandipika' Chaukhambha Sanskrit Sansthan, Varanasi, India, Reprinted in 2013, Uttar Stana 24/19, p. 155.

15. Sushruta Samhita,with Nibandha Sangraha commentary of Shree Dalhanacharya and the Nyayachandrika Panjika of Shri Gayadasacharya on Nidanasthana, edited by Keval krishan Thakral, Chaukhambha Orintalia, Varanasi Reprinted in 2019, Uttar Stana 24/20-21, p. 167.

16. Sushruta Samhita, commentaries by Shastri, Kaviraja Ambikadatta 'Ayurveda Tattva Sandipika' Chaukhambha Sanskrit Sansthan, Varanasi, India, Reprinted in 2013, Uttar Stana 24/25, p. 156.

17. Sushruta Samhita, commentaries by Shastri, Kaviraja Ambikadatta 'Ayurveda Tattva Sandipika' Chaukhambha Sanskrit Sansthan, Varanasi, India, Reprinted in 2013, Uttar Stana 24/26-29, pp. 156-157.

18. Sushruta Samhita, commentaries by Shastri, Kaviraja Ambikadatta 'Ayurveda Tattva Sandipika' Chaukhambha Sanskrit Sansthan, Varanasi, India, Reprinted in 2013, Uttar Stana 24/30-33, p. 157.

19. Sushruta Samhita, commentaries by Shastri, Kaviraja Ambikadatta 'Ayurveda Tattva Sandipika' Chaukhambha Sanskrit Sansthan, Varanasi, India, Reprinted in 2013, Uttar Stana 24/34-41, pp. 157-158.

20. Sushruta Samhita, commentaries by Shastri, Kaviraja Ambikadatta 'Ayurveda Tattva Sandipika' Chaukhambha Sanskrit Sansthan, Varanasi, India, Reprinted in 2013, Uttar Stana 24/42, p. 158.

21. Ish Sharma, Aparna Sharma. Research \& Reviews: A Journal of Pharmacognosy, 4(2), 1. ISSN: 2394-7276 (Online)

22. Ish Sharma, Aparna Sharma. Research \& Reviews: A Journal of Pharmacognosy, 4(2), 2. ISSN: 2394-7276 (Online)

Copyright: (C2020 Ish Sharma. This is an open-access article distributed under the terms of the Creative Commons Attribution License, which permits unrestricted use, distribution, and reproduction in anymedium, provided the original author and source are credited. 